\title{
Morphology Differentiation and Structural Functionality of Ewes Due to Incomplete Crossbreeding
}

\author{
Diferenciación Morfológica y Funcionalidad Estructural de Ovejas Debido a Cruzamiento Incompleto
}

\author{
${ }^{*}$ E. Latorre; ${ }^{* *}$ H. Uribe; ${ }^{* * *}$ M. E. Martínez; ${ }^{* * *}$ C. Calderón \& ${ }^{* * * *}$ R. de la Barra
}

LATORRE, E.; URIBE, H.; MARTÍNEZ, M. E.; CALDERÓN, C. \& DE LA BARRA, R. Morphology differentiation and structural functionality of ewes due to uncomplete crossbreeding. Int. J. Morphol., 29(3):954-959, 2011.

SUMMARY: Most Chilean sheep stock comprises different degrees of crossbreeding over Corriedale breed. A common absorbent crossbreeding has been Australian Merino over Corriedale which, in many cases, has not been complete. The aim of this study was to evaluate the process of morphology differentiation and structural functionality of Corriedale ewes undergoing incomplete absorbent crossbreeding which was carried out in order to create an animal with a new morphology. A total of four hundred adult ewes were measured; two hundred belonging to the incomplete crossbreeding, and two hundred from the two original breeds (one hundred Corriedale and one hundred Australian Merino ewes). All measured ewes were randomly selected. Fourteen body measurements were recorded and nine body indexes were calculated for each ewe. Results show that a new biotype has been created from the absorbent crossbreeding of Corriedale by Australian Merino, which produced ewes with a clear morphological and structural functionality differentiation as compared to the two original breeds. The new body format shows morphostructural variability coefficients that are similar to those found on other formally recognized sheep breeds.

KEY WORDS: Sheep; Breeding; Morphology.

\section{INTRODUCTION}

Development of the Chilean sheep industry has been strongly influenced by the introduction of male breeding stock coming from different breeds and origins. Most of the Chilean sheep stock corresponds to different degrees of crossbreeding-over Corriedale breed. Official census indicates that currently there exist about two and a half million sheep heads in Chile. This is in part a consequence of the genetic improvement strategy of the Magallanes Region, which historically has considered the introduction of specialized meat and ultrafine wool breeds intending to improve the production ability of the existent stock (Bianchi et al., 2006; Cardellino \& Müeller, 2008). One of the recurrent crossbreedings has been the absorption of Corriedale by Australian Merino breeds, process that, in many cases, has not been complete. This, in addition to seeking for productive changes, has produced some morphological changes of the original Corriedale breed.

The objective of this study was to evaluate the impact, on morphology and functional structure, of the differentiation process of Corriedale ewes undergoing incomplete absorbing crossbreeding. The research was mainly focused to identify new animal formats, since the first step of new animal type identification is the description of its morphological attributes (Delgado et al., 2001).

\section{MATERIAL AND METHOD}

Animal evaluation in a population of nine thousand ewes was done in summer 2010 in the Magallanes Region, Chile. This population is the product of an incomplete absorbing crossbreeding of Corriedale by Australian Merino breeds. The crossbreeding program started in 1986 via artificial insemination, and was composed by two consecutive stages. The first stage was applied in order to create a flock which was completely absorbed by Australian Merino, while the second stage was to generate a stabilized crossbreeding between both breeds. At the first crossbreeding

* INIA Kampenaike. Angamos 1056, Casilla 277, Punta Arenas, Chile.

** INIA Remehue. Carretera Panamericana Sur Km. 8 Norte, Osorno, Chile.

**** INIA Butalcura. O’Higging 415 A of. 14, Castro, Chiloé, Chile. 
stage, replacement Corriedale ewes were kept and consecutively mated to Australian Merino rams, appliying restrictive phenotypic selection. In the second stage, crossbred males were kept and mated to a Corriedale commercial flock; in this case, phenotypic selection based on productive rather than ethnological aspects was in place. As a result, two flocks with different breeds composition were obtained: the first one of one thousand ewes, almost completely absorbed by Australian Merino, in which mating scheme was assigning a known ram to an identified group of ewes. The second flock, of nine thousand incomplete absorbed commercial ewes, was randomly mated with several rams per group of ewes.

Population sample size was estimated following the method proposed by Canon \& Roe (1982).

$$
\text { Sample Sise }=1 /\left(\frac{1}{n_{1}}+\frac{1}{P o p}\right)
$$

Where:

Pop $=$ is the population size

$$
n_{1}=\frac{4 p q}{L^{2}}
$$

Being $\mathrm{p}$ proportion of individuals in the population which are expected to be of the new incomplete absorbed crossbreeding.

and $q=1-p$

$\mathrm{L}=$ accepted error.

It was assumed that $85 \%$ of the animals in the population were a specimen of the new animal format; accepted error was 5\%, and therefore sample size was estimated at two hundred ewes. Another two hundred ewes of the original pure breeds were also measured (one hundred Corriedale and one hundred Australian Merino). All measurements were done on adult randomly selected ewes. Fourteen body measurements in each ewe were recorded, as suggested by several authors (Herrera et al. 1996; Álvarez et al., 2000; Calderón et al., 2009; Herrera \& Luque, 2009; Bravo \& Sepúlveda, 2010). Body measurements were: Shank Perimeter (SP), Thorax Perimeter (ThP), Rump Length (RL), Face Length (FL), Cranial Length (CraL), Chest Width (ChW), Head Width (HW), Cranial Width (CraW), Rump Width (RW), Withers Height (WH), Rump Height (RH),
Thorax Width (TW), Body Length (BL) and Body Depth (BD).

In addition, nine body indexes were calculated from body measurements. These indexes were: Body Index (BI), Thoracic Index (ThI), Thorax Relative Depth Index (TRDI), Ilium-Ischium Index (II), Longitudinal Ilium-Ischium Index (LII), Transversal Ilium-Ischium Index (TII), Metacarpal Thoracic Index (MTI); Metacarpal Rib Index (MRI) and Shank Relative Thickness Index (SRTI). Some of the body measurements and indexes were applied following the recommendations of Herrera \& Luque, while others were calculated as proposed by Bravo \& Sepúlveda.

Structural morphology differences between the incomplete crossbreeding and the original breeds were assessed by Student's T test, comparing body measurement means. To assess structural functionality differences, the above test was also used to compare the zoometric indexes. Data were stored in an Excel electronic spreadsheet and analyzed by means of the Xlstat 2011 software.

\section{RESULTS AND DISCUSSION}

Absorbent crossbreeding is a genetic improvement method which makes use of the reproductive performance of a more numerous (absorbing) breed in order to increase the amount of individuals of a less numerous (absorbed) breed. This way, the less represented breed increases its participation in the genetic makeup of the population over time. This is a long-lasting process, in which as the crossbreeding progresses in each generation, the absorbed breed format progressively disappears and the new animal format gets closer to the absorbing breed.

The absorbing process will be finished when phenotypic changes in the animal format are imperceptible from one generation to the next, and the format of the absorbing breed is not different from the current absorbed generation. Before these two conditions are met, the population will show many transitional situations, in which a proportion of the absorbed and absorbing breed formats will join together, generating an animal format with a new underlying structure (Toro et al., 2010).

In this study, the original (absorbed) breed was Corriedale, and the absorbing breed was Australian Merino. This research was oriented to define if morphology and structural functionality of the new (incomplete crossbreeding) population was statistically different as compared to the two original breeds. Results are presented at first evaluating the 
degree of differentiation of morphology and structural functionality of the new population compared to the original breeds, and in second place, evaluating the degree of within-population homogeneity of the recorded measurements.

Morphology differentiation. The population resulting from the crossbreeding has significant morphostructural differences $(\mathrm{p}<0.01)$ as compared to Corriedale breed (Table I). The new population has longer face (FL) and smaller cranial area (CraL and $\mathrm{CraW}$ ) than Corriedale. Head differences are very important from an ethnological point of view in breed identification (Sierra, 2001; Delgado et al.; Herrera \& Luque). The morphostructural changes observed at this level correspond to an emergent ethnological format which is different to Corriedale breed.

Significant differences $(\mathrm{p}<0.01)$ are also seen for rump structure (Table I), where rump length and width (RL, $\mathrm{RW}$ ) are smaller in the new population as compared to Corriedale breed. Regarding the general body format, the resulting population has thinner shanks (SP) and narrower thoracic structure (ThP, $\mathrm{ChW}$ ), but it shows a deeper body (BD) and is taller (WH, RH) than Corriedale. This indicates a significant differentiation from Corriedale regarding its structural morphology, which evidences a better meat-purpose format than Corriedale; this was previously described by Bianchi et al., in a terminal crossbreeding of Corriedale ewes sired by meat-type breeds. Other authors have shown a relationship between these structural changes and productive performance (Yakubu, 2010; Yakubu et al., 2010a).
Table I also shows differences $(\mathrm{p}<0.01)$ between the new incomplete crossbreeding and the Australian Merino breed. It can be seen that the incomplete crossbreeding has a smaller cranial area (CraL and $\mathrm{CraW}$ ) and a narrower head (HW). These findings show that the incomplete crossbreeding not only differs from Corriedale but also differs from Australian Merino, which indicates the appearance of a new ethnological format.

As compared to Australian Merino, the incomplete crossbreeding shows narrower and shorter rump (RW, RL), thinner shanks (SP), narrower chest (ChW) and thinner body (BD). Length (BL) and height (WH, RH) are not significantly different from Australian Merino. These data support the hypotheses that the structural morphology of the new population is dissimilar than that of Australian Merino; therefore, absorption of the Corriedale breed by Australian Merino has not been complete, and a new animal format has been generated. These findings, plus the ethnological differences, are the basic concepts on the foundation of a breed (Sierra), determining the starting point of morphological aspects expressing productive value which are distinguishable for the new type of animal built up as a product of incomplete absorbing crossbreeding processes (Yakubu; Yakubu et al., 2010b).

Structural functionality differentiation. Morphostructure provides information susceptible to be used on ethnological characterization of an animal population, and allows a judgment of the productive potential based on implicit mechanical relationships within the morphological structure

Table I. Body measurement means $(\mathrm{cm})$, differences $(\mathrm{cm})$ and statistic significance $(\mathrm{T}$ test) for the difference between the two original breeds (Corriedale and Australian Merino) and the incomplete crossbreeding ewes.

\begin{tabular}{lccccc}
\hline Body Measurements & $\begin{array}{c}\text { Incomplete } \\
\text { Crossbreeding }(\mathbf{c m}) \mathbf{( 1 )}\end{array}$ & $\begin{array}{c}\text { Corriedale } \\
(\mathbf{c m}) \mathbf{( 2 )}\end{array}$ & $\begin{array}{c}\text { Difference } \\
(\mathbf{c m})(\mathbf{1 - 2})\end{array}$ & $\begin{array}{c}\text { Australian Merino } \\
(\mathbf{c m}) \mathbf{( 3 )}\end{array}$ & $\begin{array}{c}\text { Difference } \\
(\mathbf{c m})(\mathbf{1 - 3})\end{array}$ \\
\hline FL & 18.65 & 13.60 & $5.05^{*}$ & 18.17 & 0.47 \\
CraL & 7.27 & 9.40 & $-2.13^{*}$ & 10.87 & $-3.60^{*}$ \\
CraW & 7.36 & 9.47 & $-2.11^{*}$ & 10.67 & $-3.31^{*}$ \\
HW & 12.16 & 12.30 & -0.14 & 13.48 & $-1.32^{*}$ \\
ChW & 22.22 & 24.33 & $-2.10^{*}$ & 22.48 & -0.25 \\
ThP & 88.12 & 92.13 & -4.00 & 100.26 & $-12.13^{*}$ \\
RW & 12.00 & 18.30 & $-6.3 *$ & 20.17 & $-8.17^{*}$ \\
RL & 13.13 & 20.40 & $-7.26^{*}$ & 17.40 & $-4.35^{*}$ \\
SP & 8.74 & 9.61 & $-0.87^{*}$ & 13.56 & $-4.81^{*}$ \\
BD & 30.98 & 28.90 & $2.08^{*}$ & 33.52 & $-2.54^{*}$ \\
ThW & 22.7 & 24.43 & -1.73 & 25.34 & $-2.64^{*}$ \\
BL & 71.04 & 65.90 & $5.14^{*}$ & 74.85 & -3.80 \\
WH & 69.26 & 63.45 & $5.81^{*}$ & 67.25 & 2.01 \\
RH & 70.61 & 65.92 & $4.69^{*}$ & 68.45 & 2.15 \\
\hline
\end{tabular}

*p<0.01. 
Table II. Means $(\mathrm{cm})$ and variation coefficients $(\%)$ in the incomplete crossbreeding and the original breeds.

\begin{tabular}{lcccccc}
\hline $\begin{array}{l}\text { Zoometric } \\
\text { Index }\end{array}$ & $\begin{array}{c}\text { Incomplete } \\
\text { Crossbreeding }(\mathbf{c m})\end{array}$ & $\begin{array}{c}\text { Variation } \\
\text { Coefficient } \mathbf{( \% )}\end{array}$ & $\begin{array}{c}\text { Corriedale } \\
(\mathbf{c m})\end{array}$ & $\begin{array}{c}\text { Variation } \\
\text { Coefficient } \mathbf{( \% )}\end{array}$ & $\begin{array}{c}\text { Australian } \\
\text { Merino }(\mathbf{c m})\end{array}$ & $\begin{array}{c}\text { Variation } \\
\text { Coefficient }(\%)\end{array}$ \\
\hline BI & 80.7 & 5.5 & 72.0 & 11.1 & 74.8 & 4.6 \\
ThI & 73.6 & 11.8 & 84.6 & 7.0 & 76.4 & 18.4 \\
TRDI & 44.8 & 7.3 & 45.6 & 5.7 & 49.9 & 8.4 \\
II & 91.3 & 4.3 & 89.9 & 6.7 & 115.9 & 10.4 \\
LII & 19.0 & 6.5 & 32.2 & 5.4 & 26.0 & 9.8 \\
TII & 17.3 & 7.9 & 28.9 & 8.0 & 30.1 & 10.6 \\
MTI & 9.9 & 7.4 & 10.5 & 8.8 & 13.6 & 8.2 \\
MRI & 38.8 & 9.8 & 39.5 & 8.4 & 54.1 & 13.2 \\
SRTI & 12.6 & 5.2 & 15.2 & 9.2 & 20.2 & 8.5 \\
\hline
\end{tabular}

(Zaitoun et al., 2005, Yakubu et al., 2010a). Therefore, morphology expresses a strong relationship with productive potential, since it contains the structure which supports the biological functionality of the animal (Alpak et al., 2009). If this relationship is not considered, it would imply that appropriate productive life adaptation models would not be correct (Bravo \& Sepúlveda; Yakubu et al., 2010b).

Body Index (BI) indicates the relative capacity of the animal format. In this study, it was observed that the incomplete crossbreeding had a superior format as compared to the original breeds (Table II), although the three genotypes have a rectangular shape, which is predominant on meatpurpose animals (Riva et al., 2004; Salako, 2006; Herrera \& Luque; Yakubu).

Thoracic Index (TI) indicates that the incomplete crossbreeding tends to be similar to the Australian Merino elliptic format, and deviate from the more circular Corriedale format (Table II), finally being categorized as a slight dualpurpose format. Furthermore, TRDI indicates that the incomplete crossbreeding exhibits similar depth as Corriedale breed, with a medium meat production aptitude.

Metacarpal Thoracic Index (MTI) states the relationship between the body mass and the limbs holding it. A low MTI indicates that the animal has longer legs and low body weight, which is associated to higher speed; higher MTI indicates a sturdy type of animal (Bravo \& Sepúlveda). A higher proximity to the ground in the animal indicates a better efficiency for walking and grazing (Álvarez et al.; De la Barra, 2008; Herrera $\&$ Luque). MTI also provides information on skeleton thickness, being a higher MTI associated to meat-oriented animals (De la Barra). In this study, the incomplete crossbreeding presented a Corriedale-like format, which is sturdier than Australian Merino, and medium meat-oriented format. In addition, MTI of the incomplete crossbreeding indicates a functional tendency towards medium milk-production type.
Ilium-Ischium Index (II) provides an idea of the rump structure, which is associated to reproductive functionality. The incomplete crossbreeding presents a convex line identical to Corriedale, with rump length greater than rump width; consequently the Transversal Ilium-Ischium Index (TII) magnitude of the original breeds reflects dairy aptitude and easy lambing, as described by De la Barra and Bravo \& Sepúlveda.

Also, Longitudinal Ilium-Ischium Index (LII) of the incomplete crossbreeding supports the idea that there exists a dual-purpose animal format. This can be confirmed by analyzing the Shank Relative Thickness Index (SRTI), which indicates that the incomplete crossbreeding has thinner bones than the original breeds, and as a result a better meat production performance within a dual-purpose structural functionality framework (De la Barra).

Within-population homogeneity. Besides being significantly different to other breeds, a relevant aspect of the new population is the degree of morphostructure homogeneity; meaning that animals within the incomplete crossbreeding tend to be similar among them (Sierra; Salako; Traoré et al., 2008; Kunene et al., 2009). To compare homogeneity, Herrera \& Luque suggested direct comparison of the percent variation coefficients as a real morphostructural homogeneity test. Several authors have made sheep breed evaluations using this criteria: Álvarez et $a l$. for Canaria sheep; Espinace (2009) for Suffolk Down; Calderón et al. for Suffolk Down, Romney Marsh and Chilota; Bravo \& Sepúlveda for Araucana; and De la Barra et al. (2011) for Chilota. In this study, it was observed that within-population morphostructural variability of the incomplete crossbreeding is similar to that observed in other formally recognized sheep breeds.

The homogeneity of morphological characters is typical of populations that, within a process of differentiation, 
have achieved a remarkable degree of morphological stability. In this case, it can be said that the resulting population of the absorbent crossbreeding is a mature morphostructural format population; this fact allows to predict the ranges of morphostructural expression of future generations for this population, a feature which is typical of animal breeds.

\section{ACKNOWLEDGEMENTS}

The authors wish to aknowledge Mr. José Marín Antonín and Ganadera Marín's technical staff for their facilities and support on the process of data collection.

LATORRE, E.; URIBE, H.; MARTÍNEZ, M. E.; CALDERÓN, C. \& DE LA BARRA, R. Diferenciación morfológica y funcionalidad estructural de ovejas debido a cruzamiento incompleto. Int. J. Morphol., 29(3):954-959, 2011.

RESUMEN: La mayor parte del stock ovino chileno comprende diferentes grados de cruzamiento con la raza Corriedale. Un cruzamiento absorbente común ha sido el de Merino Australiano sobre Corriedale, el cual, en muchos casos, no ha sido completo. En este estudio se evaluó el proceso de diferenciación morfológica y funcionalidad estructural de las ovejas Corriedale que fueron previamente sometidas a cruzamiento absorbente incompleto con el fin de crear un animal con una nueva morfología. Se midió un total de cuatrocientas ovejas adultas, doscientas provenientes del cruzamiento incompleto y doscientas de las dos razas originales (cien ejemplares de raza Corriedale y cien de Merino australiano). Todas las ovejas medidas fueron seleccionadas al azar. Para cada animal se registraron catorce mediciones corporales y se calcularon nueve índices. Los resultados de los análisis permiten concluir que el cruzamiento absorbente de Corriedale por Merino Australiano ha generado un nuevo biotipo ovino, con una diferenciación morfológica clara y diferente funcionalidad estructural al ser comparadas con las dos razas originales. Los coeficientes de variabilidad morfoestructural que presenta el nuevo formato corporal fueron similares a los de otras razas ovinas formalmente reconocidas.

PALABRAS CLAVE: Ovino; Cruzamiento; Morfología.

\section{REFERENCES}

Alpak, H.; Onar, V. \& Mutus, R. The relationship between morphometric and long bone measurements of the Morkaraman sheep. Turk. J. Vet. Anim. Sci., 33:199-207, 2009.

Álvarez, S.; Fresno, M.; Capote, J.; Delgado, J. \& Barba, C. Estudio para la caracterización de la raza ovina Canaria. Arch. Zootec., 49:209-15, 2000.

Bianchi, G.; Garibotto, G.; Betancour, O.; Feed, O. \& Franco, J. Efecto del peso al sacrificio sobre la calidad de la canal y de la carne de cordero puros y en cruza. Arch. Med. Vet., 38(2):161-5, 2006.

Bravo, S. \& Sepúlveda, N. Índices zoométricos en ovejas criollas Araucanas. Int. J. Morphol., 28(2):489-95, 2010.

Calderón, C.; De la Barra, R.; Martínez, M. E. \& Gonzalo, C. Variabilidad fenotípica morfoestructural de las razas ovinas predominantes en Chiloé. Pucón, Chile, VII Simposio de recursos genéticos para América latina y el Caribe (SIRGEALC), 2009.

Cannon, R. M. \& Roe, R. T. Livestock Disease Surveys: A field Manual for Veterinarians. Canberra, Australian Bureau of Animal Health, 1982.
Cardellino, R. C. \& Mueller, J. P. Fibre production and sheep breeding in South America. Proc. Assoc. Advmt. Breed. Genet., 18:366-73, 2008.

De la Barra, R. Efecto de la introducción de la ganadería en el archipiélago de Chiloé, Chile. Tesis doctoral, Universidad de León, España, 2008.

De la Barra, R.; Carvajal, A.; Uribe, H., Martínez, M.E.; Gonzalo, C.; Arranz, J. J. \& San Primitivo, F. El ovino criollo Chilote y su potencial productivo. Anim. Genet. Resources, 48:1-7, 2011.

Delgado, J. V.; Barba, C.; Camacho, M. E.; Sereno, F.; Martínez, A. \& Vega-Pla, J. L. Caracterización de los animales domésticos en España. AGRI-FAO, 29:7-18, 2001.

Espinace, B. Evaluación etnológica de la raza Suffolk Down en Chile. Tesis de grado para optar al título de Médico Veterinario. Puerto Montt, Chile, Universidad Santo Tomás, 2009.

Herrera, M.; Rodero, E.; Gutiérrez, M.; Peña, F. \& Rodero, J. Application of multifactorial discriminant analysis in the morphostructural differentiation of Andalusian caprine breeds. Small Ruminant Res., 22:39-47, 1996. 
Herrera, M. \& Luque, M. Morfoestructura y sistemas para el futuro en la valoración morfológica. En: Valoración Morfológica de los animales domésticos. Sañudo, A. C. (Ed.). Madrid, Ministerio de Medio Ambiente y Medio Rural y Marino, 2009.

Kunene, N. W.; Bezuidenhout, C. C. \& Nsahlai, I. V. Genetic and phenotypic diversity in Zulu sheep populations: implications for population. Small Ruminant Res., 84:100-10, 2009.

Riva, J.; Rizzi, R.; Marelli, S. \& Cavalchini, L. G. Body measurements in Bergamasca sheep. Small Ruminant Res., 55:221-7, 2004.

Salako, A. Application of morphological indexes in the assessment of type and function in sheep. Int. J. Morphol., 24(1):13-8, 2006.

Sierra, I. El concepto de raza: evolución y realidad. Arch. Zootec., 50:547-64, 2001.

Toro, I. M. V.; Manríquez, S. G. \& Suazo, G. I. Morfometría geométrica y el estudio de las formas biológicas: De la morfología descriptiva a la morfología cuantitativa. Int. J. Morphol., 28(4):977-90, 2010.

Traoré, A.; Tamboura, H. H.; Kaboré, A.; Royo, L. J.; Fernández, I.; Álvarez, I.; Sangaré, M.; Bouchel, D.; Poivey, J. P.; Francois, D.; Toguyeni, A.; Sawadogo, L. \& Goyache, F. Multivariate characterization of morphological traits in Burkina Faso sheep. Small Ruminant Res., 80:62-7, 2008.

Yakubu, A. Path coefficient and path analysis of body weight and biometrics traits in Yankasa Lambs. Slovak. J. Anim. Sci., 43(1):17-25, 2010.

Yakubu, A.; Salako, A. E.; Imumorin, I. G.; Ige, A. O. \& Akinyemi, M. O. Discriminant analysis of morphometric differentiation in the West African Dwarf and Red Sokoto goats. S. Afr. J. Anim. Sci., 40:381-7, 2010a.

Yakubu A.; Salako, A. E. \& Imumorin, I. G. Multivariate analysis of spatial patterns of morphological traits in West African Dwarf goats in three agro-ecological zones of Nigeria. J. Appl. Anim. Res., 38:257-60, 2010 b.

Zaitoun, I.; Tabbaa, M. \& Bdour, S. Differentiation of native goat breeds of Jordan on the basis of morphostructural characteristics. Small Ruminant Res., 56:173-82, 2005.
Correspondence to:

M. E. Martínez

INIA Butalcura.

O'Higging $415 \mathrm{~A}$ of. 14

Castro, Chiloé

CHILE

Email: mariae.martinez@inia.cl

Received: 13-06-2011

Accepted: 14-07-2011 